\title{
Effect of Micronutrient Management Zinc and Boron on Crop Growth, Yield and Quality of Onion (Allium cepa L.)
}

\author{
S. Chandan*, P. L. Kumar and Deepanshu \\ Department of Horticulture, Naini Agricultural Institute, SHUATS, Prayagraj Allahabad, \\ U.P., India \\ *Corresponding author
}

\section{A B S T R A C T}

\begin{tabular}{|l|}
\hline Ke y w o r d s \\
Micronutrient, Zinc, \\
Boron, NPK, \\
growth, Bulb yield, \\
Quality and Onion \\
\hline Article Info \\
\hline $\begin{array}{l}\text { Accepted: } \\
\text { 12 December } 2020 \\
\text { Available Online: } \\
\text { 10 January } 2021\end{array}$ \\
\hline
\end{tabular}

The present study entitled "Effect of micronutrient management zinc and boron on crop growth, yield and quality of Onion (Allium cepa L.)" was undertaken in the Horticulture Research Farm, Department of Horticulture, Sam Higginbottom University of Agriculture Technology and Science, Prayagraj, 211007 during the Rabi season of 2019-2020. The Experiment was laid out in a Randomized Block Design with 10 treatments and 3 replications. Results revealed that the application of $\mathrm{T}_{9}: 3.5 \mathrm{Zn}+3.5 \mathrm{~B}+\mathrm{RDF}(100: 50: 50)$ influenced most of the characteristics significantly and recorded the highest values of plant height (73.52), number of leaves plant ${ }^{-1}(10.45)$, neck diameter $(1.42 \mathrm{~cm})$ fresh weight of bulb (94.18), dry weight of bulb (89.51), days to first bulb harvesting (49.71), diameter of bulb $(9.65 \mathrm{~cm})$, bulb yield per plot $(18.84)$, bulb yield $\left(\mathrm{t} \mathrm{ha}^{-1}\right)(62.79)$, ascorbic acid (mg/10g fresh weight) (14.35) and TSS ( ${ }^{\circ}$ Brix) (11.93).

\section{Introduction}

Onion (Allium cepa L.) is one of the most important commercial vegetable crops cultivated extensively in India and it belongs to family Alliaceae. It is liked for its flavour and pungency which is due to the presence of a volatile oil 'allyl propyl disulphide'- organic compound rich in sulphur. The bulb is a rich source of minerals like phosphorus, calcium and carbohydrates. It also contains protein and vitamin C. It has got good medicinal value.Itis one of the most important monocotyledonous, cross-pollinated and cool season vegetablecrop. Onion has its own distinctive flavor, used in soups, meat dishes, salads and sandwiches and is cooked alone as a vegetable.

India is the world's second largest producer of vegetables next to China. According to estimation, India produces 87.50 million tonnes of vegetables from an area of 5.80 million hectares. Thus, India shares about $12 \%$ of world's output of vegetables (Thamburaj and Singh, 2001). Due to lower yields, though India has the highest area under onion, it stands second in the production of onion in the world. India is also the largest exporter of onion. Productivity 
could be increased by use of suitable varieties.

Onion (Allium cepa L.), the "Queen of Kitchen" is one of the most important commercial crops not only in India but also in the world (Selvaraj,1976; Griffiths et al., 2002). It's pungency is due to the presence of volatile oil "Allyl propyl di sulphide" (Khan et al., 2007).Generally100 g of edible bulb of onion contains $86.6 \mathrm{~g}$ of moisture, $11.0 \mathrm{~g}$ of carbohydrates, $1.2 \mathrm{~g}$ of protein, $0.6 \mathrm{~g}$ of fibre and $0.4 \mathrm{~g}$ of minerals. It also contains calcium (180mg), phosphorous (50 mg), iron (0.7mg), thiamine and nicotinic acid $(0.4 \mathrm{mg})$.

Zinc plays vital role in carbohydrate metabolism. It is involved in diverse range of enzyme system. Zinc is taken up by plants as $\mathrm{Zn}+2$. The functional role of $\mathrm{Zn}$ includes auxin metabolism, influence on the activities of dehydrogenase and carbonic anhydrate enzymes, synthesis of cytochrome and stabilization or ribosomal fraction (Tisdale et al., 1984).

Boron is one of the important micronutrient for onion production and is essential for cell division, nitrogen and carbohydrate metabolism, protein formation and water relation in plant growth (Brady, 1990). Although it is quickly taken up from the soil, it is relatively immobile in the plant. It is important to maintain the correct balance of calcium, nitrogen and boron in the soil. High calcium and high nitrogen levels can reduce boron uptake. Boron deficiency has been observed in soils with high organic matter contents.

\section{Materials and Methods}

The experiment was conducted in the Horticulture Research Farm, Department of Horticulture, Naini Agricultural Institute, Sam Higginbottom University of Agriculture,
Technology and Sciences, Prayagraj during Rabi Season (October - March, 20192020). The variety used in this experiment is Nasik Red N-53, which were collected from local Prayagraj market (Alopibhag). The observations were recorded on five randomly selected plants per replication was conducted in Randomized block design (RBD) with 10 treatments and 3 replications $\mathrm{T}_{0}$ :Control, $\mathrm{T}_{1}: 3$ $\mathrm{Kg} \mathrm{Zn} \mathrm{+RDF} \mathrm{(100:50:50),} \mathrm{T}_{2}: 5 \mathrm{Kg} \mathrm{Zn} \mathrm{+RDF}$ (100:50:50), $\quad, \quad \mathrm{T}_{3}: 7 \quad \mathrm{Kg} \mathrm{Zn}+\mathrm{RDF}$ (100:50:50), $\mathrm{T}_{4}: 3 \mathrm{Kg} \mathrm{B}+\mathrm{RDF}$ (100:50:50), $\mathrm{T}_{5}: 5 \mathrm{Kg} \mathrm{B}+\mathrm{RDF}(100: 50: 50), \mathrm{T}_{6}: 7 \mathrm{Kg} \mathrm{B}$ $+\mathrm{RDF}(100: 50: 50), \mathrm{T}_{7}: 1.5+1.5 \mathrm{Zn}+\mathrm{B}+$ RDF (100:50:50), $\mathrm{T}_{8}: 2.5+2.5 \mathrm{Zn}+\mathrm{B}+\mathrm{RDF}$ $(100: 50: 50), \quad \mathrm{T}_{9}: 3.5+3.5 \mathrm{Zn}+\mathrm{B}+\mathrm{RDF}$ (100:50:50). Onion is a high nutrient requiring crop and it responsive well to nutrition.

Application of "B" can increase bulb size, no. of scales/bulb and yield of onion and application of " $\mathrm{Zn}$ " as foliar spray recorded significantly higher in plant height \&other growth parameters. Soto check this research trial was laid on "Effect of micronutrient management of Zinc and Boron on crop growth, yield and quality of Onion" with the following objectives are to find out suitable treatments of micro nutrient management along with RDF for crop growth, yield and quality of onion and to work out the economics of treatments. The significance and non - significance of the treatment effect was judged with the help of " $F$ " variance ratio test. Calculated " $\mathrm{F}$ "e value was compared with the table value of $\mathrm{F}$ "at $5 \%$ level of significance.

\section{Results and Discussion}

The Experiment was conducted to determine the "Effect of micronutrient management zinc and boron on crop growth, yield and quality of Onion (Allium cepa L)". The results of the experiment are summarized below table 0.1 
Table.1 Performance of Micro nutrient management zinc and boron on crop growth, yield and quality of onion (Allium cepa. L) N-53

\begin{tabular}{|c|c|c|c|c|c|c|c|c|c|c|c|c|}
\hline $\begin{array}{l}\text { Treatment } \\
\text { Symbol }\end{array}$ & Treatment combination & $\begin{array}{c}\text { Plant } \\
\text { height } \\
90 \text { DAS }\end{array}$ & $\begin{array}{c}\text { No.of } \\
\text { leaves } \\
\text { per } \\
\text { plant } \\
90 \\
\text { DAS }\end{array}$ & $\begin{array}{c}\text { Neck } \\
\text { diameter } \\
(\mathrm{cm})\end{array}$ & $\begin{array}{l}\text { Days to } \\
\text { first } \\
\text { bulb } \\
\text { harvesti } \\
\text { ng }\end{array}$ & $\begin{array}{c}\text { Fresh } \\
\text { weight } \\
\text { of bulb } \\
\text { (g) }\end{array}$ & $\begin{array}{c}\text { Dry } \\
\text { length } \\
\text { of } \\
\text { bulb } \\
\text { (g) }\end{array}$ & $\begin{array}{c}\text { Bulb } \\
\text { diameter } \\
(\mathbf{c m})\end{array}$ & $\begin{array}{c}\text { Bulb } \\
\text { yield } \\
\text { per } \\
\text { plot } \\
(\mathbf{k g}) \\
\mathbf{4 m ^ { 2 }}\end{array}$ & $\begin{array}{l}\text { Bulb } \\
\text { yield } \\
\text { (t/ha) }\end{array}$ & $\begin{array}{c}\text { Ascorbic } \\
\text { Acid } \\
\text { (mg/100 } \\
\text { g fresh } \\
\text { wt.) }\end{array}$ & $\begin{array}{c}\text { TSS } \\
\left({ }^{0} \text { Brix }\right) \\
(\%)\end{array}$ \\
\hline $\mathbf{T}_{\mathbf{0}}$ & Control & 55.81 & 4.95 & 1.05 & 78.85 & 63.14 & 56.82 & 6.33 & 12.63 & 31.57 & 11.68 & 10.68 \\
\hline $\mathbf{T}_{1}$ & $3 \mathrm{Kg} \mathrm{Zn}+\mathrm{RDF}(100: 50: 50)$ & 63.95 & 6.48 & 1.16 & 61.54 & 81.20 & 73.08 & 8.61 & 16.24 & 40.60 & 12.32 & 11.48 \\
\hline $\mathbf{T}_{2}$ & $5 \mathrm{Kg} Z \mathrm{Zn}+\mathrm{RDF}(100: 50: 50)$ & 64.97 & 6.16 & 1.20 & 63.52 & 78.60 & 70.74 & 9.16 & 15.72 & 39.30 & 14.20 & 11.60 \\
\hline $\mathbf{T}_{3}$ & $7 \mathrm{Kg} Z \mathrm{Zn}+\mathrm{RDF}(100: 50: 50)$ & 64.47 & 6.88 & 1.29 & 58.83 & 86.62 & 77.95 & 8.97 & 17.32 & 43.30 & 13.55 & 11.40 \\
\hline $\mathbf{T}_{4}$ & $3 \mathrm{Kg} \mathrm{B}+\mathrm{RDF}(100: 50: 50)$ & 69.47 & 7.71 & 1.25 & 51.24 & 87.85 & 79.06 & 8.58 & 17.57 & 43.92 & 14.32 & 11.56 \\
\hline $\mathbf{T}_{5}$ & 5 Kg B + RDF (100:50:50) & 68.47 & 7.65 & 1.28 & 51.60 & 82.54 & 74.28 & 8.45 & 16.51 & 41.27 & 13.10 & 11.66 \\
\hline $\mathbf{T}_{6}$ & $7 \mathrm{Kg}$ B + RDF (100:50:50) & 64.15 & 8.13 & 1.26 & 57.44 & 79.71 & 71.73 & 8.75 & 15.94 & 39.85 & 13.44 & 11.61 \\
\hline $\mathbf{T}_{7}$ & $\begin{array}{l}1.5 \mathrm{Kg} \mathrm{Zn}+1.5 \mathrm{Kg} \mathrm{B}+\mathrm{RDF} \\
(100: 50: 50)\end{array}$ & 65.74 & 9.15 & 1.38 & 56.47 & 89.32 & 80.38 & 9.34 & 17.86 & 44.65 & 13.62 & 11.84 \\
\hline $\mathbf{T}_{8}$ & $\begin{array}{l}2.5 \mathrm{Kg} \mathrm{Zn+2.5} \mathrm{Kg} \mathrm{B+RDF} \\
(100: 50: 50)\end{array}$ & 68.83 & 8.40 & 1.36 & 52.45 & 88.75 & 79.87 & 9.48 & 17.75 & 44.37 & 13.36 & 11.80 \\
\hline $\mathbf{T}_{9}$ & $\begin{array}{l}3.5 \mathrm{Kg} \mathrm{Zn}+3.5 \mathrm{Kg} \mathrm{B}+ \\
\mathrm{RDF}(100: 50: 50)\end{array}$ & 73.52 & 10.45 & 1.42 & 49.71 & 94.18 & 84.76 & 9.65 & 18.84 & 47.10 & 14.35 & 11.93 \\
\hline & F-Test & $\mathbf{S}$ & $\mathbf{S}$ & $\mathbf{S}$ & $\mathbf{S}$ & $\mathbf{S}$ & $\mathbf{S}$ & $\mathbf{S}$ & $\mathbf{S}$ & $\mathbf{S}$ & $\mathbf{S}$ & $\mathbf{S}$ \\
\hline & S.Ed. (+) & 1.566 & 0.418 & 0.024 & 0.282 & 1.656 & 0.032 & 1.118 & 0.331 & 0.019 & 0.205 & 0.282 \\
\hline & C. D. at 0.5 & 3.290 & 0.879 & 0.050 & 0.592 & 3.479 & 0.067 & 2.349 & 0.696 & 0.041 & 0.431 & 0.592 \\
\hline
\end{tabular}


The maximum plant height (73.52) was recorded in treatment $\mathrm{T}_{9}: 3.5+3.5 \mathrm{Zn}+\mathrm{B}+$ RDF (100:50:50) and the minimum plant height was recorded as (55.81) in treatment $\mathrm{T}_{0 \text { : }}$ Control.

The maximum number of leaves plant $^{-1}$ (10.45) was recorded in treatment $\mathrm{T}_{9}: 3.5+3.5$ $\mathrm{Zn}+\mathrm{B}+\mathrm{RDF}$ (100:50:50) and minimum number of leaves plant ${ }^{-1}$ was recorded as (4.95) in treatment $\mathrm{T}_{0 \text { : }}$ Control. The maximum Neck diameter $(\mathrm{cm})(1.42 \mathrm{~cm})$ was recorded in treatment $\mathrm{T}_{9}: 3.5+3.5 \mathrm{Zn}+\mathrm{B}+\mathrm{RDF}$ (100:50:50). The minimum Neck diameter (cm) $(1.05 \mathrm{~cm})$ was recorded in treatment $\mathrm{T}_{0}$ Control.

The maximum fresh weight of bulb (94.18) was recorded in treatment $\mathrm{T}_{9}: 3.5+3.5 \mathrm{Zn}+\mathrm{B}+$ RDF (100:50:50) and the minimum fresh weight of bulb (63.14) was recorded in the treatment $\mathrm{T}_{0}$ Control.

The maximum dry weight of bulb (84.76) was recorded in treatment $\mathrm{T}_{9}: 3.5+3.5 \mathrm{Zn}+\mathrm{B}+$ RDF (100:50:50) and the minimum dry weight of bulb (56.82) was recorded in the treatment $\mathrm{T}_{0}$ Control. The minimum days to first bulb harvesting (49.71) was recorded in treatment $\mathrm{T}_{9}: 3.5+3.5 \mathrm{Zn}+\mathrm{B}+\mathrm{RDF}$ (100:50:50) and maximum days to first harvesting (78.85) was recorded in treatment $\mathrm{T}_{0:}$ Control.

The maximum diameter of bulb $(9.65 \mathrm{~cm})$ was recorded in treatment $\mathrm{T}_{9}: 3.5+3.5 \mathrm{Zn}+\mathrm{B}+$ RDF (100:50:50) and minimum diameter of bulb $(6.33 \mathrm{~cm})$ was recorded in treatment $T_{0}$ : Control. The maximum bulb yield per plot (18.84) was recorded in treatment $\mathrm{T}_{9}: 3.5+3.5$ $\mathrm{Zn}+\mathrm{B}+\mathrm{RDF}$ (100:50:50) and minimum bulb yield per plot (12.63) was recorded in treatment $\mathrm{T}_{0}$ Control.

The maximum bulb yield $\left(\mathrm{t} \mathrm{ha}^{-1}\right)$ (47.10) was recorded in treatment $\mathrm{T}_{9}: 3.5+3.5 \mathrm{Zn}+\mathrm{B}+$
RDF (100:50:50) and minimum bulb yield (t $\mathrm{ha}^{-1}$ ) (31.57) was recorded in treatment $\mathrm{T}_{0}$ : Control.

The maximum ascorbic acid $(\mathrm{mg} / 10 \mathrm{~g}$ fresh weight) (14.35) was recorded in treatment $\mathrm{T}_{9}: 3.5+3.5 \mathrm{Zn}+\mathrm{B}+\mathrm{RDF}(100: 50: 50)$ and minimum ascorbic acid ( $\mathrm{mg} / 10 \mathrm{~g}$ fresh weight) (11.68) was recorded in treatment $\mathrm{T}_{0 \text { : }}$ Control. The maximum TSS ( ${ }^{0}$ Brix) (\%) (11.93) was recorded in treatment $\mathrm{T}_{9}: 3.5+3.5 \mathrm{Zn}+\mathrm{B}+$ RDF (100:50:50). The minimum TSS ( ${ }^{0}$ Brix) $(10.68 \%)$ was recorded in treatment $T_{0}$ : Control.

In conclusion among the various levels of micronutrient (Zinc and Boron) and NPK used in the experiment, treatment $\mathrm{T}_{9}: 3.5 \mathrm{Zn}+$ $3.5 \mathrm{~B}+\mathrm{RDF}$ (100:50:50) for plant height (73.52), number of leaves plant ${ }^{-1}$ (10.45), fresh weight of bulb (94.18), dry weight of bulb (84.76), days to first bulb harvesting (49.71), diameter of bulb $(9.65 \mathrm{~cm})$, bulb yield per plot (kg) (18.84), bulb yield $\left(\mathrm{t} \mathrm{ha}^{-1}\right)$ (47.10), ascorbic acid (mg/10g fresh weight) (14.35) and TSS ( ${ }^{0}$ Brix) (\%) (11.93) was the best for the maximum growth, yield and quality of onion under Prayagraj Agroclimatic condition when compared with control and the other treatments.

\section{References}

Abdul Ghaffoor, Muhammad SaleemJilani, Ghulam Khaliq and Kashif Waseem, (2003). Effect of Different NPK Levels on the Growth and Yield of Three Onion (Allium cepa L.) Varieties. Asian Journal of Plant Sciences, 2: 342-346

Alam MN, Abedin MJ, Azad MK. (2010). Effect of micronutrients on growth and yield of onion under calcareous soil environment. Int. Res. J Plt. Sci. 2010; 1(3):56-61.

Ali MDS. (2013). Effects of micronutrients on growth, yield and quality of three 
varieties of summer onion. M.Sc. Thesis, Department of Horticulture, Bangladesh Agricultural" University, Mymensingh, 2013, 60.

Babaleshwar, S.B., Koppad, S.R., Dharmatti, P.R. and Math, K.K., (2017). Impact of Micronutrients on Growth, Yield and Quality of Onion (Allium cepa), Int. J. Pure App. Biosci. 5(6): 1205- 1209

Bagali A. N., Patil H. B., Chimmad V. P., PatilandR .V. and Patil P. L. (2012). Effect of inorganics and organics on growth and yield of onion (Allium cepa L.). KarnatakaJ. Agric. Sci.,25 (1): (112-115)2012

Biswas Pooja, Shreya Das, Aloke Bar, Tapan Kumar Maity and AmitRanjanMandal (2020). Effect of Micronutrient Application on Vegetative Growth and Bulb Yield Attributes of Rabi Onion (Allium cepa Int.J.Curr.Microbiol.App.Sci (2020) 9(3):556-565

Brady, N.C. 1990. The nature and properties and soils. 10th edition, A.K. Ghosh. PrintingHall of India Pvt. Ltd., New Delhi. p. 383.

Chanchan M., Hore J. K. and Ghanti S. (2013). Response of garlic to foliar application of some micronutrients. Journal of Crop and Weed, 9(2):138141(2013) 138.

Chattopadhyay, A. and Mukhopadhyay, R. 2004. Response of onion to boron as foliar feeding. Indian Journal Ornamental Horticultre 11: 21-27.

Griffiths, G., Trueman, L., Crowther, T., Thomas, B., Smith, B. (2002). Onions A globalbenfitto health, Phytotherapy Research, (16), 7:603-615.

Khan, A.A, Zubair, M., Bari, A. and Maula. 2007. Response of onion (Allium cepa L.) growth and yield to different levels of nitrogen and zinc in swat valley. Sarhad Journal Agriculture. 23(4): $933-$
936.

Rashid MH. (2010). Effect of sulphur and GA3 on the growth and yield of onion. Prog.

Rashid, M.H.A. and Islam, M.T. (2019). Effects of micronutrients on bulb growth, yield and quality of local and high yielding onion (Allium cepa L.) cultivars in Bangladesh. Archives of Agriculture and Environmental Science, 4(3): 281-287,

Ravi Goyal, VarshaUike and HemlataVerma (2017). Effect of foliar application of micronutrients on growth and yield of onion (Allium cepa L.) c.v. Agri found dark red. Agric. Sci. Digest., 37(2) 2017: 160-162

Rohidas, S.B., Bharadiya, P.S., Jature, S.D. and Ghate, K.B. (2011). Effect of micronutrient on growth and yield of garlic (Allium satvum L.) var. G-41. Internat. J. agric. Sci., 7(1):80-82.

Selvaraj, Onion: Queen of the kitchen. Kisan World, 3(12): 32-34, 1976.

Thamburaj and Narendra Singh (2001), Textbook of vegetables tuber crops and spices. Indian council of agricultural research. Agric. 2010; 21(1-2):57-63.

Sethupathi S., Paramasivan M., Manikandan K. and Senthil N. Kumar (2019). Effect of zinc and boron on growth and yield of transplanted onion (allium cepa 1.) in alifisols of tamirabarni tract. International Journal of Agriculture Sciences,

Sethupathi, S (2019). Effect of Zinc and Boron on Yield and Quality of Onion (Allium cepa L.) in Alfisols of Tamirabarni Tract. Madras Agric. J., 2019; doi:10.29321

Tisdale, S.L., W.L. Nelson, J.D. Beaton, and J.L. Havlin. 1993. Soil fertility and fertilizers. 634 p. 5th ed. Macmillan Publishing, New York, USA. 


\section{How to cite this article:}

Chandan, S., P. L. Kumar and Deepanshu. 2021. Effect of Micronutrient Management Zinc and Boron on Crop Growth, Yield and Quality of Onion (Allium cepa L.). Int.J.Curr.Microbiol.App.Sci. 10(01): 2190-2195. doi: https://doi.org/10.20546/ijcmas.2021.1001.251 